\title{
Religiusitas, Persepsi Korupsi Pajak, Pelayanan Fiskus dan Kepatuhan Wajib Pajak
}

\author{
I Gst Ngurah Agastya Mahasurya ${ }^{1}$ \\ Fakultas Ekonomi dan Bisnis \\ Universitas Udayana, Indonesia
}

\author{
I Ketut Budiartha ${ }^{2}$ \\ Fakultas Ekonomi dan Bisnis \\ Universitas Udayana, Indonesia
}

Surel : agastyamahasurya04@gmail.com

ABSTRAK

Penelitian ini bertujuan untuk menguji pengaruh religiusitas, persepsi korupsi pajak, dan pelayanan fiskus terhadap kepatuhan wajib pajak orang pribadi. Penelitian ini dilaksanakan di Kantor Pelayanan Pajak Pratama Tabanan Bali. Metode analisis data yang digunakan adalah regresi linier berganda. Sampel dalam penelitian ini adalah WPOP yang terdaftar di KPP Pratama Tabanan dengan jumlah responden sebanyak 100 orang. Metode penentuan sampel menggunakan convenience sampling, dan data dikumpulkan menggunakan kuesioner. Berdasarkan hasil penelitian menunjukkan bahwa religiusitas, persepsi korupsi pajak, dan pelayanan fiskus berpengaruh terhadap kepatuhan wajib pajak orang pribadi di KPP Pratama Tabanan. Hal ini menunjukan religiusitas, persepsi korupsi pajak, dan pelayanan fiskus dapat membantu wajib pajak untuk menjalankan kewajibannya akan kepatuhan perpajakannya.

Kata Kunci: Religiusitas; Persepsi Korupsi Pajak; Pelayanan Fiskus; Kepatuhan Wajib Pajak Orang Pribadi.

\section{The Effect of Religiosity, Tax Corruption Perception and Fiscus Services Against WPOP Compliance in Tabanan KPPP}

\section{ABSTRACT}

This study aims to examine the effect of religiosity, perceptions of tax corruption, and the tax authorities on individual taxpayer compliance. This research was conducted at the Tabanan Primary Tax Service Office in Bali. The data analysis method used is multiple linear regression. The sample in this study was WPOP registered at Tabanan Primary Tax Office with 100 respondents. The method of determining the sample using convenience sampling, and data collected using a questionnaire. Based on the results of the study showed that religiosity, perceptions of tax corruption, and fiscal services affect the compliance of individual taxpayers in the Tabanan Primary Tax Office. This shows that religiosity, perceptions of tax corruption, and fiscal services can help taxpayers to carry out their tax compliance obligations.

Keywords: Religiosity; Perception of Tax Corruption; Fiscus Services; Personal Taxpayer Compliance.

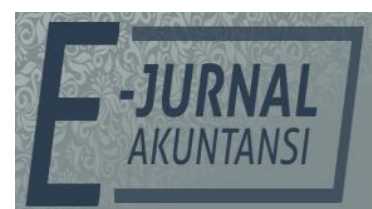

e-ISSN 2302-8556

Vol. 30 No. 11

Denpasar, Nopember 2020

Hal. 2713-2723

DOI:

10.24843/EJA.2020.v30.i11.p01

PENGUTIPAN:

Mahasurya, I G.N.A. \& Budiartha, I K. (2020).

Religiusitas, Persepsi Korupsi Pajak, Pelayanan Fiskus dan Kepatuhan Wajib

Pajak. E-Jurnal Akuntansi, 30(11), 2713-2723

RIWAYAT ARTIKEL: Artikel Masuk: 4 Februari 2020 Artikel Diterima: 21 Juli 2020

Artikel dapat diakses : https://ojs.unud.ac.id/index.php/Akuntansi/index 


\section{PENDAHULUAN}

Kantor Pelayanan Pajak Pratama Tabanan merupakan instansi yang bertanggung jawab langsung kepada Kepala Kantor Direktorat Jenderal Pajak Wilayah Bali. Penelitian ini meneliti tentang kepatuhan wajib pajak orang pribadi yang terdaftar di KPP Pratama Tabanan. Tingkat kepatuhan wajib pajak orang pribadi di KPP Tabanan dari sisi pelaporan SPT juga masih berfluktuasi. Fluktuasi tingkat pelaporan SPT, dapat dilihat pada Tabel 1.

Tabel 1. Tingkat Kepatuhan Wajib Pajak Orang Pribadi dalam Pelaporan SPT di KPP Pratatama Tabanan Tahun 2015 - 2018

\begin{tabular}{lllll}
\hline Tahun & $\begin{array}{l}\text { WPOP } \\
\text { Terdaftar }\end{array}$ & $\begin{array}{l}\text { WPOP } \\
\text { Efektif }\end{array}$ & $\begin{array}{l}\text { WPOP yang } \\
\text { Menyampaikan SPT }\end{array}$ & $\begin{array}{l}\text { Kepatuhan } \\
(\%)\end{array}$ \\
\hline 2015 & 100.214 & 76.791 & 39.492 & 51,43 \\
2016 & 108.018 & 84.413 & 47.915 & 56,76 \\
2017 & 116.909 & 93.198 & 45.366 & 48,68 \\
2018 & 113.429 & 51.972 & 44.071 & 84,80 \\
\hline
\end{tabular}

Sumber: KPP Pratama Tabanan, 2019

Berdasarkan Tabel 1, dapat dilihat bahwa tingkat kepatuhan wajib pajak orang pribadi di Tabanan dalam pelaporan SPT mengalami fluktuasi dari tahun 2015-2018. Dengan perhitungan SPT tahunan PPh pribadi dibagi dengan wajib pajak orang pribadi yang terdaftar dikali 100\% . Di dapat tahun 2016 mengalami peningkatan dari tahun 2015 yang awalnya hanya 51,43 persen meningkat menjadi 56,76 persen. Tahun 2017, kembali mengalami penurunan tingkat kepatuhan hingga mencapai 48,68 persen. Pelaporan SPT kembali seiring dengan upaya meningkatkan penerimaan negara dari sektor pajak yaitu tax amnesty pada tahun 2018 yaitu sebesar 84,80 persen.

Dengan adanya permasalahan pada kepatuhan wajib pajak kususnya pada wajib pajak yang terdaftar di KPP Pratama Tabanan yang mengalami fluktuasi, itu mengakibatkan terganggunya penerimaan pajak pada. Kepatuhan wajib pajak yang tidak mengalami peningkatan akan mengganggu upaya pemerintah untuk meningkatkan kesejahteraan masyarakat (Chau \& Leung, 2009). Tingkat kepatuhan wajib pajak yang rendah merupakan satu masalah serius yang dihadapi bagi para pembuat kebijakan ekonomi (Togler, 2005). Kepatuhan wajib pajak menjadi hal yang penting untuk ditingkatkan guna mencapai pembangunan ekonomi dan kesejahteraan masyarakat.

Menurut Mahendra \& Sukartha (2014) komponen kepatuhan wajib pajak terdiri atas kepatuhan mendaftarkan diri, kepatuhan untuk membayar kewajiban pajak (tepat jumlah dan tepat waktu) dan kepatuhan untuk melaporkan kewajiban pajak (tepat jumlah dan tepat waktu). Kepatuhan pajak adalah kondisi dimana wajib pajak bersedia untuk memenuhi kewajiban pajaknya sesuai dengan aturan yang berlaku.

Tingkat kepatuhan wajib pajak dipengaruhi oleh dua hal yaitu lingkungan internal dan lingkungan eksternal (Widagsono, 2017). Faktor internal merupakan faktor yang berasal dari diri Wajib Pajak itu sendiri dan berhubungan dengan karakteristik individu dalam menjalankan kewajiban perpajakannya, termasuk keyakinan terhadap Tuhan atau religiusitas wajib pajak yang mampu menentukan kepatuhan perpajakan. Sedangkan faktor eksternal adalah faktor yang berasal dari luar diri Wajib Pajak seperti situasi dan lingkungan sekitar 
wajib pajak, seperti kualitas pelayanan dan dorongan dari lingkungan sekitar. Religiusitas merupakan keyakinan yang dimiliki oleh wajib pajak terhadap Tuhan. Hal ini berarti, melanggar peraturan perpajakan sama seperti melanggar perintah dari Tuhan (Basri \& Surya, 2016). Hal ini membuktikan bahwa semakin kuatnya keyakinan terhadap agama maka tingkat kepatuhan wajib pajak akan semakin baik.

Faktor lain disamping Religiusitas, yang turut mengambil peran dalam memengaruhi kepatuhan wajib pajak, yakni persepsi korupsi pajak. Persepsi korupsi pajak merupakan pengamatan yang dilakukan oleh wajib pajak terhadap tindakan melawan hukum yang dilakukan oleh petugas pajak, dengan cara pengelapan uang pajak atau penyahlahgunaan wewenang, yang bertujuan untuk memperkaya diri sendiri, dan merugikan pihak lain serta kas negara (Rachmania, 2016). Dalam teori atribusi persepsi korupsi pajak merupakan faktor internal yang dapat mempengaruhi persepsi wajib pajak dalam membayar pajak. Semakin banyak perilaku petugas pajak yang menyimpang dalam melaksanakan tugasnya, seperti petugas pajak yang melakukan tindak korupsi pajak, akan berdampak pada menurunnya kepercayaan masyarakat terhadap lembaga perpajakan, dan akan membuat masyarakat untuk enggan membayar pajak. Tak ubahnya bagaimana perilaku petugas pajak dalam memberikan pelayanan kepada wajb pajak. Seperti contoh kasus Gayus Tambunan pada tahun 2011 dan kasus Dhana Widyatmika pada tahun 2012 (Adhimatra \& Noviari, 2018). Kasus tersebut membentuk persepsi wajib pajak yang menilai bahwa uang hasil pajak yang mereka bayarkan tidak dikelola dengan benar dan jujur.

Wajib Pajak memiliki persepsi bahwa korupsi hanya merupakan pemberitaan atas perusakan aturan yang dilakukan oleh para oknum pajak tanpa melihat faktor-faktor penyebab korupsi. Selain itu, sifat pajak adalah kontraprestasi dimana pengelolaan penerimaan pajak tidak dapat dirasakan secara langsung. Hal ini diperkuat dengan penelitian yang dilakukan Sari (2011) Susanto (2013), Safitri \& Tambun (2017) dan Putra (2011) yang menunjukan bahwa adanya pengaruh yang signifikan antara persepsi korupsi pajak terhadap kepatuhan wajib pajak.

Tingkat kepatuhan wajib pajak juga dapat dipengaruhi oleh faktor lainnya, salah satunya adalah pelayanan fiskus. Pelayanan fiskus merupakan suatu pelayanan oleh petugas pajak yang diberikan kepada wajib pajak untuk mengatasi kesulitan yang dialami oleh wajib pajak (Puri, 2014). Sistem perpajakan Indonesia yang menggunakan sistem self assesesment tidaklah mudah dilaksanakan. Sistem ini menuntut masyarakat utamanya wajib pajak untuk mengerti dan memahami tentang pentingnya pajak bagi negara, serta mengetahui tentang ketentuan-ketentuan perpajakan di Indonesia. Namun tidak semua penduduk atau wajib pajak memiliki pemahaman tentang aturan perpajakan. Kemauan wajib pajak untuk membayar pajak sebagian besar dipengaruhi oleh kualitas pelayanan fiskus (Palda \& Hanousek, 2002). Penelitian yang dilakukan oleh Widyastuti (2015) menunjukkan bahwa pelayanan fiskus memiliki pengaruh positif pada kepatuhan wajib pajak.

Kabupaten Tabanan, dijadikan fokus dalam melakukan penelitian terkait kepatuhan wajib pajak yang terdaftar di KPP Pratama Tabanan. Sebagai informasi awal, tingkat kepatuhan wajib pajak orang pribadi di Kabupaten 
Tabanan bisa dilihat melalui tingkat pencapaian pelaporan wajib pajak orang pribadi di KPP Pratama Tabanan dari sisi pelaporan SPT menurut jenisnya. Dapat dilihat pada tabel 2.

Tabel 2. Pelaporan SPT di KPP Pratama Tabanan 2015 - 2018

\begin{tabular}{llllll}
\hline \multirow{2}{*}{ No } & \multirow{2}{*}{ Tahun } & \multicolumn{3}{c}{ Jenis SPT } & \multirow{2}{*}{ Jumlah } \\
\cline { 3 - 5 } & & 1770 & 1770 S & $1770 S S$ & \\
\hline 1 & 2015 & 2.332 & 11.863 & 25.297 & 39.492 \\
2 & 2016 & 2.904 & 15.403 & 29.600 & 47.915 \\
3 & 2017 & 3.737 & 18.976 & 22.653 & 45.366 \\
4 & 2018 & 3.697 & 19.600 & 20.774 & 44.071 \\
Jumlah & & 12.670 & 65.842 & 98.332 & 176.844 \\
\hline
\end{tabular}

Sumber: KPP Pratama Tabanan, 2019

Berdasarkan Tabel 2, dapat dilihat bahwa tingkat kepatuhan wajib pajak orang pribadi di Tabanan dalam pelaporan SPT menurut jenis nya. 1770 ( untuk wajib pajak dalam negeri dengan penghasilan dari kegiatan usaha dan melakukan pekerjaan bebas) sebanyak 3.697, 1770 S ( untuk wajib pajak dalam negeri yang bekerja dengan penghasilan pertahun di atas Rp. 60 juta) sebanyak 19.600, 1770SS (untuk wajib pajak dalam negeri yang bekerja dengan penghasilan per tahun di bawah Rp. 60 juta) sebanyak 20.774, pada tahun 2018 dengan jumlah 44.071 orang.

Religiusitas merupakan nilai-nilai keagamaan yang luhur dari Tuhan Yang Maha Kuasa yang dapat memberikan kesadaran bagi wajib pajak dalam melaksanakan kewajiban perpajakannya. Berdasarkan Theory of Planned Behavior pada bagian behavioral beliefs dikatakan bahwa keyakinan individu akan hasil dari suatu perilaku. Apabila wajib pajak memiliki keyakinan bahwa pajak yang dibayar akan digunakan untuk pembangunan nasional, maka dengan adanya peranan nilai agama, diharapkan dapat memicu perilaku positif dan mencegah perilaku negatif terhadap kepatuhan perpajakan melalui keyakinan agama yang kuat sehingga mendorong naiknya perilaku kepatuhan wajib pajak.

Penelitian yang dilakukan oleh Salsabila (2018), Raihan \& Hudayati (2018), Mohdali \& Pope (2013) menyatakan bahwa religiusitas berpengaruh positif terhadap kepatuhan wajib pajak orang pribadi. Penelitian yang dilakukan Utama (2016) menunjukan bahwa religiusitas interpersonal berpengaruh positif signifikan terhadap kepatuhan wajib pajak. Berdasarkan atas landasan teori serta penelitian sebelumnya, maka dapat dirumuskan hipotesis berikut:

$\mathrm{H}_{1}$ : Religiusitas berpengaruh positif terhadap Kepatuhan Wajib Pajak Orang Pribadi pada KPP Pratama Tabanan.

Persepsi korupsi pajak merupakan pengamatan yang dilakukan oleh wajib pajak terhadap tindakan melawan hukum yang dilakukan oleh petugas pajak, dengan cara pengelapan uang pajak atau penyahlahgunaan wewenang, yang bertujuan untuk memperkaya diri sendiri, dan merugikan pihak lain serta kas negara (Rachmania, 2016). Berdasarkan Theory of Planned Behavior pada bagian Normative belief dikatakan bahwa keyakinan tentang harapan normatif orang lain orang lain yang memotivasi seseorang untuk memenuhi harapan tersebut. Persepsi korupsi pajak merupakan faktor internal yang dapat mempengaruhi persepsi wajib pajak dalam membayar pajak. 
Penelitian yang dilakukan oleh Sari (2011), Safitri \& Tambun (2017) dan Putra (2011) yang menunjukan bahwa adanya pengaruh yang signifikan antara persepsi korupsi pajak terhadap kepatuhan wajib pajak. Penelitian yang dilakukan oleh Susanto (2013) menyatakan Semakin banyak perilaku petugas pajak yang menyimpang dalam melaksanakan tugasnya, seperti petugas pajak yang melakukan tindak korupsi pajak, akan berdampak pada menurunnya kepercayaan masyarakat terhadap lembaga perpajakan, dan akan membuat masyarakat untuk enggan membayar pajak. Tak ubahnya bagimana perilaku petugas pajak dalam memberikan pelayanan kepada wajib pajak menunjukan bahwa persepsi korupsi pajak berpengaruh negatif terhadap kepatuhan wajib pajak. Berdasarkan atas landasan teori serta penelitian sebelumnya, maka dapat dirumuskan hipotesis berikut.

$\mathrm{H}_{2}$ : Persepsi Korupsi Pajak berpengaruh negatif terhadap Kepatuhan Wajib Pajak Orang Pribadi pada KPP Pratama Tabanan.

Pelayanan fiskus adalah kewajiban petugas pajak dalam membantu dan menyiapkan segala keperluan yang dibutuhkan wajib pajak guna mengurus permasalahan pajaknya. Berdasarkan Theory of Planned Behavior pada bagian control beliefs dikatakan bahwa keyakinan akan keberadaan hal-hal yang mendukung atau penghambat perilaku yang akan ditampilkan seseorang. Dengan adanya pelayanan yang baik dari petugas pajak kepada wajib pajak serta penyuluhan-penyuluhan pajak yang baik diharapkan memberikan motivasi kepada wajib pajak agar taat dalam peraturan perpajakan yang berlaku dan diharapkan dapat meningkatkan kepatuhan perpajakannya.

Penelitian yang dilakukan oleh Puri (2014) menyatakan bahwa pelayanan fiskus berpengaruh positif terhadap kepatuhan wajib pajak. Penelitian yang dilakukan oleh Widyana \& Putra (2020) serta Wilda (2015) juga menyatakan bahwa pelayanan fiskus berpengaruh positif pada kepatuhan wajib pajak. Berdasarkan atas landasan teori serta penelitian sebelumnya, maka dapat dirumuskan hipotesis berikut:

$\mathrm{H}_{3}$ : Pelayanan Fiskus berpengaruh positif terhadap Kepatuhan Wajib Pajak Orang Pribadi pada KPP Pratama Tabanan.

\section{METODE PENELITIAN}

Populasi dalam penelitian ini adalah jumlah seluruh wajib pajak orang pribadi efektif yang terdaftar pada Kantor Pelayanan Pajak Pratama Tabanan. Kriteria pemilihan sampel yang digunakan adalah sebagai berikut: Wajib Pajak Orang Pribadi yang terdaftar di KPP Tabanan Jumlah sampel ditentukan dengan menggunakan rumus Slovin, dimana rumusnya sebagai berikut.

$$
n=\frac{N}{\left(N e^{2}\right)+1}
$$

Keterangan:

$$
\begin{aligned}
& \mathrm{n}=\text { Jumlah sampel } \\
& \mathrm{N}=\text { Ukuran populasi } \\
& \mathrm{e}=\text { Batas kesalahan (10 persen) }
\end{aligned}
$$

Berdasarkan data, populasi berjumlah 51.972 orang, maka berdasarkan rumus slovin didapatkan sampel sebanyak. 


$$
n=\frac{51.972}{51.972\left(0,1^{2}\right)+1}=99,80
$$

Berdasarkan rumus slovin, didapatkan angka 99,80 yang peneliti bulatkan menjadi 100 sampel. Dari 100 sampel tersebut terdapat 65 orang WPOP dengan kode 1770, 11 orang WPOP kode 1770S, 24 orang WPOP kode 1770SS.

Analisis regresi digunakan untuk memprediksi pegaruh lebih dari satu variabel independen terhadap satu variabel dependen. Pada penelitian ini analisis regresi linier berganda ini digunakan untuk mengetahui pengaruh kualitas pelayanan, religiusitas, dan norma subjektif terhadap kepatuhan wajib pajak orang pribadi yang terdaftar di kantor pelayanan pajak pratama Tabanan. Berikut model regresi dalam penelitian ini.

$Y=\alpha+\beta 1 X 1+\beta 2 X 2+\beta 3 X 3+\varepsilon$

Keterangan:

$\mathrm{Y}=$ kepatuhan wajib pajak

$\alpha=$ konstanta

$\beta 1=$ koefisien variabel religiusitas

$\beta 2=$ koefisien variabel persepsi korupsi pajak

$\beta 3=$ koefisien variabel pelayanan fiskus

$\varepsilon=$ error

\section{HASIL DAN PEMBAHASAN}

Statistik deskriptif berhubungan dengan pengumpulan dan peringkat data yang menggambarkan karakteristik dari masing-masing variabel yang digunakan dalam penelitian ini. Analisis ini berguna untuk menjelaskan karakteristik dari variabel penelitian diantaranya: nilai rata-rata (mean), nilai ekstrim yaitu nilai minimum dan nilai maksimum, standar deviasi serta $\mathrm{N}$ yang merupakan jumlah responden dalam penelitian ini. Hasil dari deskriptif tersebut dapat dilihat pada Tabel 3 berikut.

Tabel 3. Hasil Statistik Deskriptif

\begin{tabular}{llllll}
\hline & $\mathrm{N}$ & Minimum & Maximum & Mean & Std. Deviation \\
\hline Religiusitas $\left(\mathrm{X}_{1}\right)$ & 100 & 11 & 20 & 16,34 & 2,302 \\
Persepsi Korupsi Pajak $\left(\mathrm{X}_{2}\right)$ & 100 & 6 & 15 & 12,46 & 1,920 \\
Pelayanan Fiskus $\left(\mathrm{X}_{3}\right)$ & 100 & 11 & 20 & 15,83 & 1,843 \\
Kepatuhan Wajib Pajak $(\mathrm{Y})$ & 100 & 5 & 16 & 12,57 & 1,833 \\
\hline
\end{tabular}

Sumber: Data Penelitian, 2020

Variabel religiusitas memiliki nilai minimum sebesar 11,00 dan nilai maksimum sebesar 20,00. Nilai rata-rata untuk variabel religiusitas adalah sebesar 16,34 dengan penyimpangan sebesar 2,302. Variabel persepsi korupsi pajak memiliki nilai minimum sebesar 6,00 dan nilai maksimum sebesar 15,00. Nilai rata-rata untuk variabel persepsi korupsi pajak adalah sebesar 12,46 dengan penyimpangan sebesar 1,920. Variabel pelayanan fiskus memiliki nilai minimum sebesar 11,00 dan nilai maksimum sebesar 20,00. Nilai rata-rata untuk variabel pelayanan fiskus adalah sebesar 15,83 dengan penyimpangan sebesar 1,843. Variabel kepatuhan wajib pajak memiliki nilai minimum sebesar 5,00 dan nilai maksimum sebesar 16,00 . Nilai rata-rata untuk variabel kepatuhan wajib pajak adalah sebesar 12,57 dengan penyimpangan sebesar 1,833 . 
Berdasarkan hasil pengolahan data dengan bantuan SPSS, maka didapatkan hasil sebagai berikut.

Tabel 4. Hasil Analisis Regresi Linier Berganda

\begin{tabular}{|c|c|c|c|c|c|}
\hline \multirow[t]{2}{*}{ Variabel } & \multicolumn{2}{|c|}{$\begin{array}{l}\text { Unstandardized } \\
\text { Coefficients }\end{array}$} & \multirow{2}{*}{$\begin{array}{l}\text { Standardized } \\
\text { Coefficients } \\
\text { Beta } \\
\end{array}$} & \multirow[t]{2}{*}{$\mathrm{t}$} & \multirow[t]{2}{*}{ Signifikansi } \\
\hline & B & Std. Eror & & & \\
\hline (Constant) & 3,233 & 1,656 & & 1,949 & 0,054 \\
\hline $\mathrm{X}_{1}$ & 0,205 & 0,067 & 0,257 & 3,043 & 0,003 \\
\hline$X_{2}$ & $-0,173$ & 0,072 & $-0,204$ & $-2,414$ & 0,018 \\
\hline$X_{3}$ & 0,496 & 0,083 & 0,498 & 5,940 & 0,000 \\
\hline Adjusted R Square & 0,323 & & & & \\
\hline F Hitung & 16,737 & & & & \\
\hline Signifikansi F & 0,000 & & & & \\
\hline
\end{tabular}

Sumber: Data Penelitian, 2020

Berdasarkan Tabel 4, dapat disusun persaman regresi sebagai berikut.

$$
Y=3,233+0,205 X_{1}-0,173 X_{2}+0,496 X_{3}
$$

Diketahui nilai konstanta (a) sebesar 3,233 mengandung arti jika nilai variabel bebas yaitu Religiusitas $\left(X_{1}\right)$, Persepsi Korupsi Pajak $\left(X_{2}\right)$ dan Pelayanan Fiskus $\left(X_{3}\right)$ tidak berubah atau sama dengan nol, maka nilai Kepatuhan Wajib Pajak (Y) akan naik sebesar 3,233 satuan atau dengan kata lain kepatuhan wajib pajak meningkat.

Nilai $\beta_{1}=0,205$; berarti apabila variabel Religiusitas meningkat, maka akan mengakibatkan peningkatan terhadap Kepatuhan Wajib Pajak dengan asumsi variabel bebas lainnya dianggap konstan.

Nilai $\beta_{2}=-0,173$; berarti apabila variabel Persepsi Korupsi Pajak meningkat, maka akan mengakibatkan penurunan terhadap Kepatuhan Wajib Pajak dengan asumsi variabel bebas lainnya konstan.

Nilai $\beta_{3}=0,496$; berarti apabila variabel Pelayanan Fiskus meningkat, maka akan mengakibatkan peningkatan terhadap Kepatuhan Wajib Pajak dengan asumsi variabel bebas lainnya konstan.

Besarnya nilai koefisien determinasi ditunjukkan dengan nilai Adjusted $\mathrm{R}$ square $\left(R^{2}\right)$ adalah 0,323. Hasil ini berarti bahwa pengaruh variabel Religiusitas, Persepsi Korupsi Pajak, dan Pelayanan Fiskus pada Kepatuhan Wajib Pajak sebesar $32,3 \%$ dan sisanya $67,7 \%$ dipengaruhi oleh faktor - faktor lain diluar model penelitian.

Berdasarkan hasil regresi Tabel 4, siginifikansi F sebesar 0,000 $<0,05$ maka variabel independen berpengaruh serempak (simultan) terhadap variabel dependen. Hal ini berarti seluruh variabel independen (religiusitas, persepsi korupsi pajak dan pelayanan fiskus) dapat memprediksi atau menjelaskan fenomena kepatuhan wajib pajak orang pribadi di Kantor Pelayanan Pajak Pratama Tabanan, sehingga dapat disimpulkan bahwa model dalam penelitian ini dikatakan layak untuk diteliti.

Hipotesis pertama penelitian ini menyatakan bahwa religiusitas berpengaruh positif terhadap kepatuhan wajib pajak orang pribadi. Hasil perhitungan uji $t$ dapat dilihat pada Tabel 4 yang menunjukkan variabel kualitas pelayanan memiliki nilai koefisien regresi sebesar 0,205 dengan tingkat signifikansi sebesar 0,003 lebih kecil dibandingkan taraf nyata a=0,05 yang 
menunjukkan bahwa variabel religiusitas memiliki pengaruh terhadap kepatuhan wajib pajak orang pribadi. Nilai koefisien regresi sebesar 0,205 menunjukkan hubungan positif antara religiusitas dengan kepatuhan wajib pajak orang pribadi, yang bermakna semakin tinggi tingkat religiusitas maka kepatuhan wajib pajak orang pribadi dalam membayar kewajiban perpajakannya akan semakin meningkat $\left(\mathrm{H}_{1}\right)$ diterima.

Hipotesis kedua penelitian ini menyatakan bahwa persepsi korupsi pajak berpengaruh negatif terhadap kepatuhan wajib pajak orang pribadi. Hasil perhitungan uji $\mathrm{t}$ dapat dilihat pada Tabel 4 yang menunjukkan variabel kualitas pelayanan memiliki nilai koefisien regresi sebesar -0,173 dengan tingkat signifikansi sebesar 0,018 lebih kecil dibandingkan taraf nyata $\mathrm{a}=0,05$ yang menunjukkan bahwa variabel persepsi korupsi pajak memiliki pengaruh terhadap kepatuhan wajib pajak orang pribadi. Nilai koefisien regresi sebesar 0,173 menunjukkan hubungan negatif antara persepsi korupsi pajak dengan kepatuhan wajib pajak orang pribadi, yang bermakna semakin tinggi tindak korupsi pajak maka kepatuhan wajib pajak orang pribadi dalam membayar kewajiban perpajakannya akan semakin menurun, maka hipotesis $\left(\mathrm{H}_{2}\right)$ diterima.

Hipotesis ketiga penelitian ini menyatakan bahwa pelayanan fiskus berpengaruh positif terhadap kepatuhan wajib pajak orang pribadi. Hasil perhitungan uji t dapat dilihat pada Tabel 4 yang menunjukkan variabel norma subjektif memiliki nilai koefisien regresi sebesar 0,496 dengan tingkat signifikansi sebesar 0,000 lebih kecil dibandingkan taraf nyata $a=0,05$ yang menunjukkan bahwa variabel pelayanan fiskus memiliki pengaruh terhadap kepatuhan wajib pajak orang pribadi. Nilai koefisien regresi sebesar 0,496 menunjukkan hubungan positif antara pelayanan fiskus dengan kepatuhan wajib pajak orang pribadi, yang bermakna semakin meningkatnya pelayanan yang baik dari petugas pajak maka kepatuhan wajib pajak orang pribadi dalam membayar kewajiban perpajakannya akan semakin meningkat, maka hipotesis $\left(\mathrm{H}_{3}\right)$ diterima.

Memiliki tingkat religiusitas yang kuat dapat mencegah seseorang berperilaku menyimpang dari ketentuan yang telah ditetapkan. Dalam hal perpajakkan, apabila seorang individu memiliki tingkat religiusitas yang tinggi, maka individu tersebut akan merasa takut melakukan suatu kecurangan atau menghindar dari kewajiban yang seharusnya dilakukan karena ia percaya bahwa apapun yang dilakukannya selalu dalam pengawasan Tuhan Yang Maha Esa.

Penelitian yang dilakukan oleh Salsabila (2018), Raihan \& Hudayati (2018), Mohdali \& Pope (2013) menyatakan bahwa religiusitas berpengaruh positif terhadap kepatuhan wajib pajak orang pribadi. Penelitian yang dilakukan Utama (2016) menunjukan bahwa religiusitas interpersonal berpengaruh positif signifikan terhadap kepatuhan wajib pajak.

Berdasarkan Theory of Planned Behavior pada bagian behavioral beliefs dikatakan bahwa keyakinan individu akan hasil dari suatu perilaku. Apabila wajib pajak memiliki keyakinan bahwa pajak yang dibayar akan digunakan untuk pembangunan nasional, maka dengan adanya peranan nilai agama, diharapkan dapat memicu perilaku positif dan mencegah perilaku negatif terhadap kepatuhan perpajakan melalui keyakinan agama yang kuat sehingga mendorong naiknya perilaku kepatuhan wajib pajak. 
Persepsi korupsi pajak digunakan wajib pajak untuk mengamati prilaku menyimpang dari petugas pajak. Dalam hal perpajakkan, apabila petugas pajak melakukan tindak korupsi atau tindakan yang memperkaya diri sendiri itu akan mengakibatkan wajib pajak tidak patuh terhadap kewajiban pajaknya.

Penelitian yang dilakukan oleh Sari (2011), Safitri \& Tambun (2017) dan Putra (2011) yang menunjukan bahwa adanya pengaruh yang signifikan antara persepsi korupsi pajak terhadap kepatuhan wajib pajak. Penelitian yang dilakukan oleh Susanto (2013) menyatakan Semakin banyak perilaku petugas pajak yang menyimpang dalam melaksanakan tugasnya, seperti petugas pajak yang melakukan tindak korupsi pajak, akan berdampak pada menurunnya kepercayaan masyarakat terhadap lembaga perpajakan, dan akan membuat masyarakat untuk enggan membayar pajak. Tak ubahnya bagimana perilaku petugas pajak dalam memberikan pelayanan kepada wajib pajak menunjukan bahwa persepsi korupsi pajak berpengaruh negatif terhadap kepatuhan wajib pajak.

Persepsi korupsi pajak merupakan pengamatan yang dilakukan oleh wajib pajak terhadap tindakan melawan hukum yang dilakukan oleh petugas pajak, dengan cara pengelapan uang pajak atau penyahlahgunaan wewenang, yang bertujuan untuk memperkaya diri sendiri, dan merugikan pihak lain serta kas negara (Rachmania, 2016). Berdasarkan Theory of Planned Behavior pada bagian Normative belief dikatakan bahwa keyakinan tentang harapan normatif orang lain orang lain yang memotivasi seseorang untuk memenuhi harapan tersebut. Persepsi korupsi pajak merupakan faktor internal yang dapat mempengaruhi persepsi wajib pajak dalam membayar pajak.

Pelayanan fiskus dari KPP Pratama Tabanan dapat dilihat dari kondisi gedung, teknologi dan fasilitas yang tersedia, serta pelayanan dari fiskus pajak. Kondisi ruangan yang memadai dan nyaman, dapat memberikan kesan nyaman dan tidak membosankan ketika harus menunggu giliran. Begitu pula dengan pelayanan yang baik dan ramah dari fiskus pajak dalam memberikan penjelasan atau menjawab pertanyaan dari wajib pajak, dapat memberikan kepuasan dan pemahaman bagi wajib pajak.

Penelitian yang dilakukan oleh Puri (2014) menyatakan bahwa pelayanan fiskus berpengaruh positif terhadap kepatuhan wajib pajak. Penelitian yang dilakukan oleh Widyana \& Putra (2020) serta Wilda (2015) juga menyatakan bahwa pelayanan fiskus berpengaruh positif pada kepatuhan wajib pajak.

Berdasarkan Theory of Planned Behavior pada bagian control beliefs dikatakan bahwa keyakinan akan keberadaan hal-hal yang mendukung atau penghambat perilaku yang akan ditampilkan seseorang. Dengan adanya pelayanan yang baik dari petugas pajak kepada wajib pajak serta penyuluhanpenyuluhan pajak yang baik diharapkan memberikan motivasi kepada wajib pajak agar taat dalam peraturan perpajakan yang berlaku dan diharapkan dapat meningkatkan kepatuhan perpajakannya.

\section{SIMPULAN}

Penelitian ini mendukung teori atribusi yaitu kepatuhan wajib pajak dipengaruhi oleh faktor inernal dan eksternal. Faktor internal merupakan faktor yang berasal dari diri wajib pajak itu sendiri, yakni tingkat religiusitas dan persepsi korupsi 
pajak. Sementara itu, faktor eksternal adalah faktor yang berasal dari luar diri wajib pajak seperti pelayanan fiskus. Dengan demikian, religiusitas, persepsi korupsi pajak dan pelayanan fiskus memberikan pengaruh signifikan terhadap tingkat kepatuhan wajib pajak. Penelitian ini sebagai motivasi bagi Kantor Pelayanan Pajak Pratama Tabanan untuk dapat meningkatkan fasilitas yang ada dan dapat memberikan sosialisasi secara rutin agar wajib pajak dapat mengetahui perkembangan dan informasi mengenai perpajakan. Selain itu Kantor Pelayanan Pajak Pratama Tabanan diharapkan dapat memberikan segala informasi yang diperlukan wajib pajak untuk meningkatkan kepatuhan wajib pajak.

\section{REFERENSI}

Adhimatra, A. A. G. W., \& Noviari, N. (2018). Faktor Yang Memengaruhi Kepatuhan Wajib Pajak Orang Pribadi Pada Kantor Pelayanan Pajak Pratama Denpasar Timur. Jurnal Akuntansi Universitas Udayana, 25(1), 717744.

Basri, Y. M., \& Surya, R. A. S. (2016). Pengaruh Keadilan, Norma Ekspektasi, Sanksi Dan Religiusitas Terhadap Niat Dan Ketidak Patuhan Pajak. Akuntabilitas, 7(3), 162-176. https://doi.org/10.15408/akt.v7i3.2733

Chau, G., \& Leung, P. (2009). A critical review of Fischer's tax compliance model: A research systhesis. International Accounting, Auditing and Taxation, 1(2), 3440.

Mahendra, P. P., \& Sukartha, I. M. (2014). Pengaruh Kepatuhan, Pemeriksaan, dan Penagihan Pajak Pada Penerimaan Pajak Penghasilan Badan. E-Jurnal Akuntansi Universitas Udayana, 9(3), 1-20.

Mohdali, R., \& Pope, J. (2013). The influence of religiosity on taxpayers' compliance attitudes: Empirical evidence from a mixed-methods study in Malaysia. Accounting Research Journal, 27(1), 71 - 91.

Palda, F., \& Hanousek, J. (2002). Quality of Government Services and the Civic Duty to Pay Taxes in the Czech and Slovak Republics, and other Transition Countries. Accounting and Finance, 1(1), 1-20.

Puri, K. A. (2014). Pengaruh Kesadaran Wajib Pajak, Pelayanan Fiskus, Dan Sanksi Pajak Terhadap Kepatuhan Wajib Pajak Orang Pribadi Yang Melakukan Kegiatan Usaha Dan Pekerjaan Bebas. Jurrnal Univesitas Muhammadiyah Surakarta, 1(1), 1-20.

Putra, F. R. (2011). Dampak Kasus Penggelapan Pajak di Indonesia terhadap Kepatuhan Wajib Pajak di Kota Padang. Universitas Putra Indonesia Padang.

Rachmania, F. (2016). Pengaruh Persepsi Korupsi Pajak Dan Kualitas Pelayanan Fiskus Terhadap Kepatuhan Wajib Pajak (Studi pada Wajib Pajak Orang Pribadi yang Terdaftar di KPP Pratama Batu). Jurnal Perpajakan (JEJAK), 10(1), 1-20.

Raihan, A. D., \& Hudayati, A. (2018). Pengaruh Norma Subyektif, Keadilan Perpajakan, Religiusitas, Dan Self Efficacy Terhadap Kepatuhan Wajib Pajak Orang Pribadi. Simposium Nasional Akuntansi XXI, 1(1), 1-27.

Safitri, D., \& Tambun, S. (2017). Pengaruh Kesadaran Wajib Pajak Dan Persepsi Korupsi Pajak Terhadap Kepatuhan Wajib Pajak Dengan Kepercayaan Masyarakat Sebagai Variabel Moderating. Media Akuntansi Perpajakan, 2(2), 
23-33.

Retrieved

from

http://journal.uta45jakarta.ac.id/index.php/MAP/article/view/1094

Salsabila, N. U. (2018). Pengaruh Religiusitas, Nasionalisme, Kepercayaan Pada Otoritas, Dan Tax Amnesty Terhadap Kepatuhan Wajib Pajak Orang Pribadi (Studi Empiris Pada Kantor Pelayanan Pajak Pratama Surakarta). Universitas Islam Indonesia Yogyakarta.

Sari, D. P. (2011). Persepsi Wajib Pajak terhadap Dunia Perpajakan Indonesia setelah Fenomena Kasus "Gayus Tambunan" dengan Pende-katan Triangulasi. Simposium Nasional Akuntansi XIV , 1(1), 1-20.

Susanto, J. N. (2013). Pengaruh Persepsi Pelayanan Aparat Pajak, Persepsi Pengetahuan Wajib Pajak, dan Persepsi Pengetahuan Korupsi terhadap Kepatuhan: Kajian Empiris Pada Wajib Pajak Orang Pribadi yang Memiliki Usaha di Kota Purbalingga Kecamatan Mayangan. Jurnal Akunatansi, 1(1), 120.

Togler, B. (2005). Direct Democracy and Tax Morale. European Journal of Political Economy, 21(3), 525-531.

Utama, A. (2016). Pengaruh religiusitas terhadap perilaku kepatuhan wajib pajak orang pribadi di provinsi DKI Jakarta. Jurnal Lingkar Widyaiswara, 3(2), 1-13.

Widagsono, S. (2017). Pengaruh Pengetahuan Perpajakan, Sanksi, dan Religiusitas terhadap Kepatuhan Wajib Pajak (Studi Kasus pada KPP Pratama Kepanjen). Universitas Islam Negeri Maulana Malik Ibrahim Malang.

Widyana, D. P. G., \& Putra, I. N. W. A. (2020). Pengaruh Kesadaraan Wajib Pajak, Pelayanan Fiskus, Dan Sanksi Pajak Terhadap Kepatuhan Wajib Pajak Kendaraan Bermotor. E-Jurnal Akuntansi, 21(1), 1-9.

Widyastuti, E. (2015). Pengaruh Tingkat Pemahaman Wajib Pajak, Kualitas Pelayanan Fiskus, Sanksi Perpajakan, dan Lingkungan Wajib Pajak Terhadap Tingkat KepatuhanWajb Pajak Orang Pribadi di KPP Pratama Surakarta. Univesitas Muhammadiyah Surakarta.

Wilda, F. (2015). Pengaruh Kesadaran Wajib Pajak, Pelayanan Fiskus dan Sanksi Pajak Terhadap Kepatuhan WPOP Yang Melakukan Kegiatan Usaha dan Pekerjaan Bebas di Kota Padang. 1-22. 